María Ema Molas ${ }^{1,2}$

Hernando Knobel ${ }^{2,3}$

Olivia Ferrández ${ }^{4}$

Marta de Antonio Cuscó ${ }^{4}$

Nuria Carballo Martínez ${ }^{4}$

Cristina Rodríguez $\mathrm{Caba}^{5}$

Sonia Luque ${ }^{4}$

Ana Guelar ${ }^{3}$

Silvia Castañeda Espinosa ${ }^{3}$

Santiago $\mathrm{Grau}^{4}$

\section{Impact of the COVID-19 pandemic: Community and hospital shared pharmaceutical care model. Satisfaction and acceptability of patients with HIV infection on antiretroviral treatment}

\author{
${ }^{1}$ Infectious Diseases Department, Hospital de la Santa Creu i Sant Pau, Barcelona, Spain. \\ ${ }^{2}$ Department of Medicine, Universitat Autònoma de Barcelona, Barcelona, Spain \\ ${ }^{3}$ Infectious Diseases Department, Hospital del Mar, Barcelona, Spain. \\ ${ }^{4}$ Pharmacy Department, Hospital del Mar, Barcelona, Spain. \\ ${ }^{5}$ Official College of Pharmacists of Barcelona, Barcelona, Spain
}

Article history

Received: 26 March 2021; Revision Requested: 4 June 2021; Revision Received: 4 September 2021; Accepted: 9 September 2021; Published: 26 November 2021

\section{ABSTRACT}

Background. The health crisis due to the COVID-19 pandemic is a challenge in the dispensing of outpatient hospital medication (OHM). Models of Antiretroviral Therapy (ART) based on community pharmacy support (ARTCP) have proven to be successful. The aim was to evaluate the degree of satisfaction, acceptability and limitations of the implementation of ARTCP, in the context of a pandemic, in our environment.

Methods. Descriptive cross-sectional study carried out in a Barcelona hospital, during the months of July-November 2020. A telephone survey was carried out via a questionnaire on the quality dimensions of the model (degree of satisfaction, acceptability) and associated inconveniences. Data collected: demographics, antiretroviral treatment (ART), concomitant medication, drug interactions (DDIs), CD4 lymphocyte count and plasma viraemia. Data analysis included descriptive statistics.

Results. A total of 533 (78.0\%) HIV patients receiving ART were included. 71.9\% (383/533) of these patients were very satisfied and $76.2 \%$ preferred attending the community pharmacy rather than the hospital. The mean satisfaction rating was 9.3 (DS: 1.4). The benefits reported were: 1) proximity to home $(406: 76.1 \%)$; 2) lower risk of contagion of COVID-19 (318: 59.7\%); 3) shorter waiting time (201: 37.1\%); 4) time flexibility $(104: 19.5 \%)$; 5) reduction of financial expenses (35: 6.57\%). A total of 11 (2\%) patients reported no benefit. Only 22.9\% reported disadvantages associated with ARTCP: 1) lack of privacy (65: 12.2\%); 2) lack of coordinationorganization (57: 10.7\%).

Conclusion. The COVID-19 pandemic has had an impact

Correspondence:

Santiago Grau Cerrato

Pharmacy Department, Hospital del Mar, Barcelona, Spain

Telephone: +34 600695281

Fax: +34 932483254

E-mail:90126@parcdesalutmar.cat on the provision of pharmaceutical care for HIV patients. The ARTPC model has proved efficient, with patients reporting a high degree of satisfaction.

Keywords: Antiretroviral therapy, pharmaceutical care; COVID-19

Impacto de la pandemia COVID-19: Modelo de atención farmacéutica compartida comunitaria y hospitalaria. Satisfacción y aceptabilidad de pacientes con infección VIH en tratamiento antirretroviral

\section{RESUMEN}

Introducción. La crisis sanitaria por la pandemia COVID-19 plantea un desafío en la dispensación de la medicación hospitalaria de dispensación ambulatoria (MHDA). Los modelos de terapia antirretroviral basados en el apoyo de la farmacia comunitaria (TARFC) han demostrado tener éxito. El objetivo del estudio fue evaluar el grado de satisfacción, aceptabilidad y limitaciones de la implementación del TARFC, en contexto de pandemia, en nuestro entorno.

Métodos. Estudio descriptivo transversal realizado en un hospital de Barcelona, durante los meses de julio-noviembre del 2020. Se realizó una encuesta telefónica, mediante un cuestionario sobre dimensiones de calidad del modelo (grado de satisfacción, aceptabilidad) e inconvenientes asociados. Se recogieron datos: demográficos, tratamiento antirretroviral (TAR), medicación concomitante, interacciones farmacológicas (DDIs), recuento de linfocitos CD4 y viremia plasmática. El análisis de datos incluyó estadistica descriptiva.

Resultados. Se incluyeron 533 pacientes $\mathrm{VIH}$ adherentes al TAR. El 71,9\% (383/533) de pacientes estaban muy satisfechos y el 76,2\% preferian acudir a la farmacia comunitaria frente a la hospitalaria. La calificación de satisfacción media fue de 9,3 (DS: 1,4). Los beneficios reportados fueron: 1) cercanía al domicilio $(406: 76,1 \%)$; 2 ) menor riesgo de contagio 
de COVID-19 (318: 59,7\%) 3) menor tiempo de espera (201: $37,1 \%)$; 4) flexibilidad horaria (104: 19,5\%); 5) reducción de gastos económicos (35: 6,57\%). Un total de 11 (2\%) pacientes no reportaron ningún beneficio. Únicamente el 22,9\% reportaron desventajas asociadas al TARFC: 1) falta de privacidad $(65: 12,2 \%) ; 2)$ falta de coordinación-organización $(57: 10,7 \%)$

Conclusión. La pandemia de COVID-19 tiene un impacto en la prestación de atención farmacéutica al VIH. El modelo TARFC ha resultado eficiente con un elevado grado de satisfacción por parte de los pacientes.

Palabras clave: tratamiento antirretroviral, modelo de atención farmacéutica; COVID-19

\section{INTRODUCTION}

The COVID-19 pandemic is putting great pressure on health systems around the world [1], with important consequences for both public health, as well as the function of health structures together with the practicing of their professionals. Due to this situation, alternatives to the hospital administration of antiretroviral medication have had to be sought. In order to guarantee an adequate provision of services, as well as to promote decongestion in hospitals and combat viral spread [2], a series of measures were carried out to ensure patient access to medication. Community pharmacies are essential services authorized to continue their activity during the emergency [3], and community pharmacists are in a key position to provide priority responses to a pandemic, including the management of patients with chronic diseases [4].

Previous studies [5-7] carried out under different settings $[8,9]$ evaluated the feasibility, acceptability and results of a differentiated model of ART dispensing based on the community pharmacy, demonstrating good clinical results (viral suppression, CD4 counts), a higher rate of adherence to ART [10] and the better acceptance of treatment by these patients.

Although the aforementioned studies have been carried out in countries with a healthcare system different from ours, as Canada and the United States, the results point towards a positive benefit derived from the inclusion of community pharmacies in the healthcare process.

In this context, CatSalut issued a resolution with the Official College of Pharmacists of Barcelona and the Hospital del Mar, in which the dispensing of OHM medication was contemplated in the non-face-to-face mode, including dispensing via community pharmacies. The present study aims to evaluate the satisfaction of HIV patients on ART in the setting of an ART dispensing model via community pharmacies, during the pandemic.

\section{MATERIAL AND METHODS}

Design and scope of the study. Patients. OHM Dispensing Circuit Through Community Pharmacies. Telematic visits. Evaluation of the satisfaction of patients adhered to the shared care model. Data collected. Statistical analysis.

\section{RESULTS}

Participants and characteristics of antiretroviral treatment. A total of 533 HIV patients were included in the study from a cohort of 683 HIV patients adhered to ART who, at the time of the study, agreed to participate in the project of shared pharmaceutical care with community pharmacies. 150 (21.9\%) patients were excluded (Figure 1).

The characteristics of the patients included are summarized in Table 1. The majority (73.5\%) were Caucasian and men (82.6\%), the mean age was 48 years (DS: 11.9$) .75 .2 \%$ (401/533) of patients received triple ART regimens, 108 (20.3\%) dual therapy patients and 22 (4.1\%) monotherapy patients.

The antiretroviral treatment used by the 533 patients included can be summarized as 57\% (304/533) received regimens based on integrase inhibitors (INI); $18.9 \%$ received regimens based on non-analog reverse transcriptase (NNRTI); 13.9\% took a protease inhibitor potentiated based therapy; $86.1 \%$ of patients received nucleoside / nucleotide analog reverse transcriptase; and 10.8\% other combination regimens. Triple therapy was used by $75.2 \%$, and mono or dual therapy by $24.4 \%$ of patients.

The co-medicated patients were 57\% (304/533), with a median of 3 drugs per patient and with $16.7 \%$ of patients taking 5 or more drugs. Recreational or abuse drugs were taken by 33\% of patients 33\% and 6\% of them for "chem-sex" purposes. Among the prescribed drugs, the most frequent were: psychotropic drugs (anxiolytics 14.3\%, antidepressants $13.9 \%$, anticonvulsants $8.1 \%$, neuroleptics $4.5 \%$, methadone 4.5\%); anti-hypertensive (ACE inhibitors or angiotensin receptor blockers $12.1 \%$ beta blockers $5.3 \%$, diuretics $4.7 \%$, calcium-channel blockers 4.5\%) lipid-lowering and oral antidiabetics (statins 15.2\%, fibrates 5.3\%, oral antidiabetics 4.3\%; proton pump inhibitors $10.9 \%$ Vitamin and mineral supplements represented $24.6 \%$ of the concomitant drugs.

DDls were detected in 109 patients (20.4\%); 26 (23.4\%) were considered potential weak interaction $73(67 \%)$ potential interaction, and $10(9 \%)$ contraindicated. In the latter, the potentiated protease inhibitor (darunavir/cobiscitat) is involved in $80 \%$ of cases with: budenoside (2 cases), quetiapine, bisoprolol, domperidone, phenitoine, midazolam, lercandipine. Rilpivirine was involved in 2 cases with: eslicarbazepine and omeprazole.

Qualitative cross-sectional survey of the new ART dispensing model. Table 2 describes the results gathered from the satisfaction questionnaire $(n=533)$. At the time of the survey, $49.2 \%(262 / 533)$ of patients had visited the community pharmacy at least 3 times to collect ART, 40.2\% (214/533) 2 times, and only 6.8\% (36/533) once. Most of the patients (71.9\% (383/533)) were very satisfied and preferred to go to the community pharmacy to collect ART (406: 76.2\%); the mean score was 9.3 (DS: 1.4) on a scale of 1 to 10 points, with 10 being the maximum satisfaction. The benefits reported by the patients were: 1) proximity to home (406: 76.1\%); 2) 


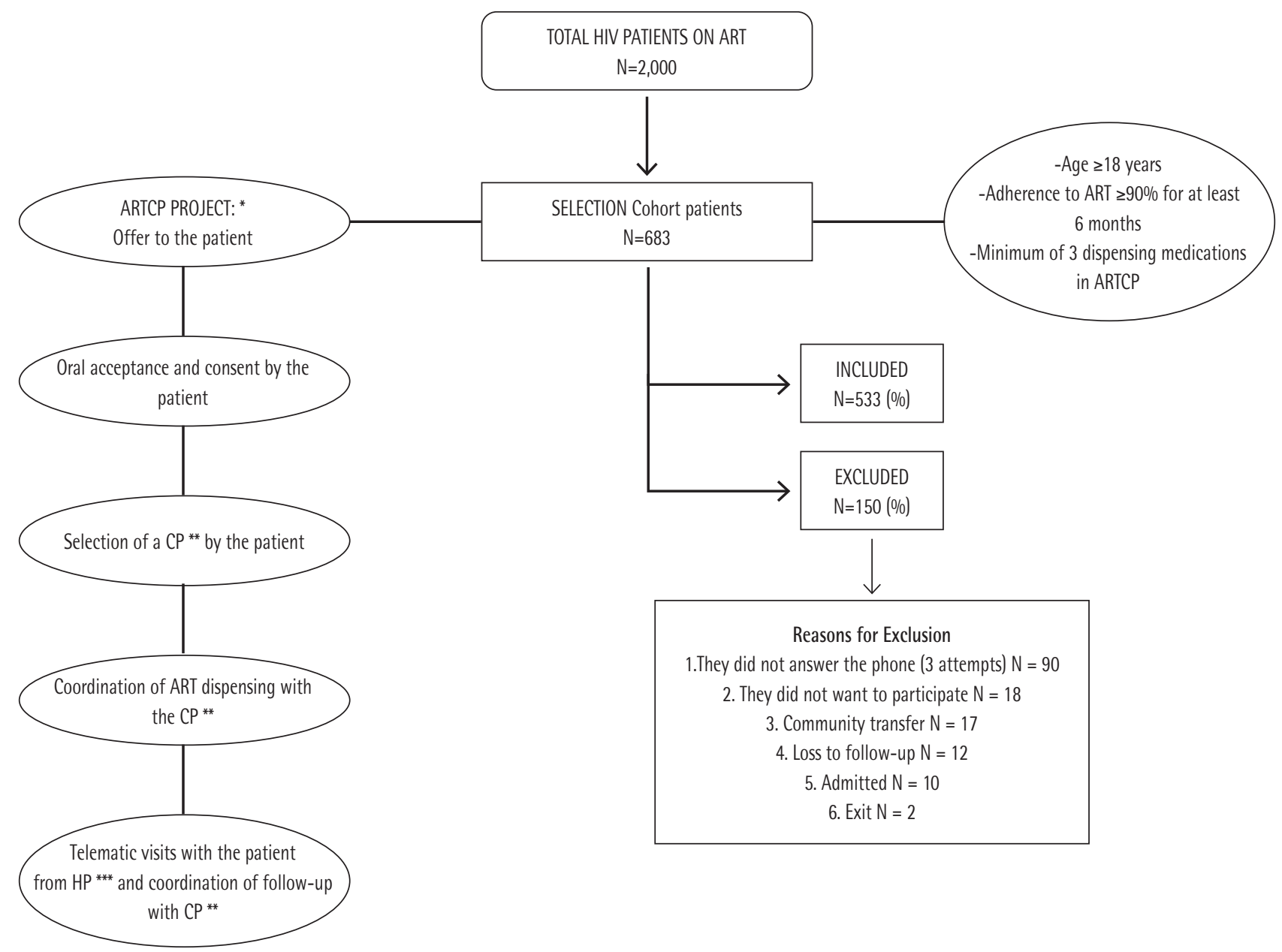

\begin{tabular}{l|l} 
Figura 1 & Flowchart: Patient selection and ART dispensing circuit integrating the community pharmacy (ATRCP).
\end{tabular}

* ARTCP: antiretroviral treatment based on community pharmacy; ART: antiretroviral treatment

${ }^{*} \mathrm{CP}$ : community pharmacy

${ }^{* * *}$ HP: Hospital Pharmacy

lower risk of contagion of COVID-19 (318: 59.66\%); 3) shorter waiting time (201: 37.1\%); 4) time flexibility (104: 19.5\%); 5) reduction of expenses (especially for public transport) (35: 6.57\%). A total of $11(2 \%)$ patients reported no benefit. Most patients $(411 / 533 ; 77.1 \%)$ confirmed that they did not encounter any problems. The main limitations reported were: 1) lack of privacy preservation (65: 12.2\%); 2) lack of coordination in the organization (Hospital Pharmacy-Community Pharmacy (57: 10.7\%).

\section{DISCUSSION}

The approach to shared pharmaceutical care between community and hospital pharmacies in dispensing $\mathrm{OHM}$, with the leadership of the hospital pharmacy, is expanding into new practice settings and includes improved patient care services, especially for those with chronic diseases [12-14], and particularly in patients living with HIV $[15,16]$.

The integration of the community pharmacy into an ART dispensing program, coordinated from the hospital pharmacy, was conceived in response to the COVID-19 pandemic during the most restrictive confinement period, out of concern that patients would interrupt ART due to difficulties in travelling to the hospital, and for security reasons, avoiding overcrowding of patients in the hospital pharmacy and thus reducing the risk of spreading COVID-19. The present study describes the experience and can be considered successful. $71.9 \%$ of the patients were very satisfied and most of them preferred to continue 


\begin{tabular}{|c|c|c|}
\hline Table 1 & \multicolumn{2}{|c|}{ Participant's characteristics } \\
\hline Characteristi & & 533 \\
\hline Men, $n(\%$ & & $440(82.6)$ \\
\hline Women, $n$ & & $93(17.4)$ \\
\hline Mean, age & & $48.33(11.96)$ \\
\hline \multicolumn{3}{|c|}{ Ethnicity n (\%) } \\
\hline Caucasian & & $392(73.5)$ \\
\hline Hispanic & & $116(21.8)$ \\
\hline Arab & & $10(1.9)$ \\
\hline Asian & & $7(1.3)$ \\
\hline African & & $8(1.5)$ \\
\hline \multicolumn{3}{|c|}{ Toxic habits, n (\%) } \\
\hline Smoking & & $226(42.4)$ \\
\hline Alcohol ce & & $10(1.9)$ \\
\hline Consumpt & Irugs of abuse & $117(22)$ \\
\hline "Chem Sex & & $32(6)$ \\
\hline \multicolumn{3}{|l|}{ HIV } \\
\hline CD4T cells & edian (IOR) & 800 (610-1008) \\
\hline Viral Supp & $<50$ copies / mL, n (\%) & $526(98.7)$ \\
\hline Detectabl & ween $20-100$ copies / mL, $n(\%)$ & $6(1.12 \%)$ \\
\hline Detectable & 00 copies / mL, n (\%) & $1(0.19 \%)$ \\
\hline \multicolumn{3}{|c|}{ ATR characteristics, n $(\%)$} \\
\hline Monother & & $22(4.1)$ \\
\hline Biotherap & & $108(20.3)$ \\
\hline Triple the & & 401 (75.2) \\
\hline \multicolumn{3}{|c|}{ Concomitant medication, n (\%) } \\
\hline Total pati & & $304(57)$ \\
\hline Polypharn & drugs & $89(16.7)$ \\
\hline DDls & & $109(20.5)$ \\
\hline
\end{tabular}

* DS: Standard deviation; IOR: Interquartile range; CV: viral load; DDls: Drug-drug interaction

with the implemented model. A low percentage of patients (14.8\%) stated that they were indifferent when choosing the service provider (Hospital Pharmacy versus Community Pharmacy), while only $9 \%$ preferred dispensing in the hospital environment. This indicates that the program has possibilities for improvement, in terms of confidentiality and coordination between pharmaceutical teams.

The findings of our study confirm the observations in the literature of the benefits reported, such as the flexible hours offered by the community pharmacy [17], and the easy access, both temporal and geographic [18] during the current health emergency. This demonstrates not only that the community

\begin{tabular}{|c|c|c|c|}
\hline \multirow{2}{*}{$\begin{array}{c}\text { Table } 2 \\
\text { Quality dimensions }\end{array}$} & \multicolumn{3}{|c|}{$\begin{array}{l}\text { Descriptive analysis of the results } \\
\text { of the satisfaction questionnaire: } \\
\text { ART dispensing model based on the } \\
\text { Community Pharmacy ( } n=533 \text { ) }\end{array}$} \\
\hline & & Description & $\mathrm{n}(\%)$ \\
\hline \multirow{3}{*}{\multicolumn{2}{|c|}{ 1. Degree of satisfaction }} & Very satisfied & $383(71.9 \%)$ \\
\hline & & Satisfied & $139(26.1 \%)$ \\
\hline & & Dissatisfied & $11(2.1 \%)$ \\
\hline \multirow{3}{*}{\multicolumn{2}{|c|}{$\begin{array}{l}\text { 2. Acceptance } \\
\text { (dispensing preference) }\end{array}$}} & Community Pharmacy & 406 (76.2) \\
\hline & & Hospital Pharmacy & $48(9 \%)$ \\
\hline & & Indifferent & $79(14.8 \%)$ \\
\hline \multirow{3}{*}{\multicolumn{2}{|c|}{$\begin{array}{l}\text { 3. Accessibility } \\
\text { (choice of community pharmacy) }\end{array}$}} & Pharmacy close to home & $453(85 \%)$ \\
\hline & & Pharmacy away from home & $41(7.7 \%)$ \\
\hline & & Indifferent & $39(7.3 \%)$ \\
\hline \multirow{4}{*}{\multicolumn{2}{|c|}{$\begin{array}{l}\text { 4. Score } \\
\text { (score from } 0 \text { to 10) }\end{array}$}} & $9-10$ & $379(71.1)$ \\
\hline & & $7-8$ & $138(25.9)$ \\
\hline & & $5-6$ & $10(1.9)$ \\
\hline & & $<5$ & $6(1.2)$ \\
\hline
\end{tabular}

pharmacy can participate in the dispensing of ART, but also that they can contribute to reduce the burden on the hospital health system [19]

The value of the clinical pharmacist as a member of a multidisciplinary HIV care team resulted in improvements in ART adherence [18], in the detection of DDIs, as well as in the quality of prescription and patient safety [20]. It would be interesting to carry out specific training in the area of patient care in ART for community pharmacists. Indeed, in the present study, $20.5 \%$ of DDIs that could be detected early were identified.

The main limitation of this study is that it was carried out in a cohort of stable HIV patients, with optimal adherence to ART (selected by computerized registries of the Hospital Pharmacy), therefore it is subject to selection bias. Specific studies would be required in patients with suboptimal adherence, or risk thereof (cultural barrier, social problem, psychiatric disorder) in order to evaluate whether community pharmaceutical care continues to offer the benefits and safety it has demonstrated in highly adherent patients.

The COVID-19 pandemic has valued shared pharmaceutical care between community and hospital pharmacy and will likely reveal new roles that they could play in our environment, beyond the pandemic.

\section{FUNDING}

None to declare 


\section{CONFLICTS OF INTEREST}

The authors declare no conflict of interest

\section{REFERENCES}

1. Koster ES, Philbert D, Bouvy ML. Impact of the COVID-19 epidemic on the provision of pharmaceutical care in community pharmacies. Res Soc Adm Pharm. 2021;17(1):2002-4.

2. Sum ZZ, Ow CJW. Community pharmacy response to infection control during COVID-19. A cross-sectional survey. Res Soc Adm Pharm. 2021;17(1):1845-52.

3. Giua C, Paoletti G, Minerba L, Malipiero G, Melone G, Heffler E, et al. Community pharmacist's professional adaptation amid COVID-19 emergency: a national survey on Italian pharmacists. Int J Clin Pharm. 2021;1-8.

4. Strand MA, Bratberg J, Eukel $H_{1}$ Hardy M, Williams C. Community Pharmacists' Contributions to Disease Management During the COVID-19 Pandemic. Prev Chronic Dis. 2020;17:E69.

5. Hirsch JD, Rosenquist A, Best BM, Miller TA, Gilmer TP. Evaluation of the first year of a pilot program in community pharmacy: HIVI AIDS medication therapy management for Medi-Cal beneficiaries. J Manag Care Pharm. 2009;15(1):32-41.

6. Kibicho J, Owczarzak J. A patient-centered pharmacy services model of HIV patient care in community pharmacy settings: a theoretical and empirical framework. AIDS Patient Care. 2012;26(1):20-8.

7. Castillo E, Palepu A, Beardsell A, Akagi L, Yip B, Montaner JSG, et al. Outpatient pharmacy care and HIV viral load response among patients on HAART. AIDS Care. 2004;16(4):446-57.

8. Asieba I0, Oqua DA, Wutoh AA, Agu KA, Omeh OI, Adeyanju ZA, et al. Antiretroviral therapy in community pharmacies - Implementation and outcomes of a differentiated drug delivery model in Nigeria. Res Social Adm Pharm. 2021;17(5):842-849. doi: 10.1016/j. sapharm.2020.06.0259.

9. Avong YK, Aliyu GG, Jatau B, Gurumnaan R, Danat N, Kayode GA, et al. Integrating community pharmacy into community based anti-retroviral therapy program: A pilot implementation in Abuja, Nigeria. PLoS ONE 2018;13(1):e0190286. doi: 10.1371/journal. pone.0190286.

10. Cocohoba JM, Murphy P, Pietrandoni G, Guglielmo BJ. Improved antiretroviral refill adherence in HIV-focused community pharmacies. J Am Pharm Assoc. 2012;52(5):e67-73.

11. Liverpool HIV Interactions. [cited $14^{\text {th }}$ of February 2021]. Available at: https://www.hiv-druginteractions.org/

12. Barnett MJ, Frank J, Wehring $H_{1}$ Newland B, VonMuenster $S$, Kumbera $\mathrm{P}$, et al. Analysis of pharmacist-provided medication therapy management (MTM) services in community pharmacies over 7 years. J Manag Care Pharm. 2009;15(1):18-31.

13. Isetts BJ, Schondelmeyer SW, Artz MB, Lenarz LA, Heaton AH, Wadd $W B$, et al. Clinical and economic outcomes of medication therapy management services: the Minnesota experience. J Am Pharm Assoc. 2008:48(2):203-14.
14. Cranor CW, Bunting BA, Christensen DB. The Asheville Project: longterm clinical and economic outcomes of a community pharmacy diabetes care program. J Am Pharm Assoc. 2003;43(2):173-84.

15. Cocohoba J, Hsu T, Greenblatt RM. Community Pharmacy Use Patterns of Women with HIV and Women At Risk for HIV in the San Francisco Bay Area. J Pharm Technol. 2010;26(5):271-5.

16. Burde A, O'Connor S, Hachey D. Community Pharmacy Enhanced Dispensing Model to Improve Medication Access for Rural Patients Living with HIV. Innov Pharm. 2019;10(4):11.

17. Mugavero MJ, Norton WE, Saag MS. Health care system and policy factors influencing engagement in HIV medical care: piecing together the fragments of a fractured health care delivery system. Clin Infect Dis. 2011;52 Suppl 2:S238-246.

18. Kauffman $Y$, Nair $V_{1}$ Herist $K$, Thomas $V$, Weidle PJ. HIV medication therapy management services in community pharmacies. J Am Pharm Assoc. 2012;52(6):e287-91.

19. Kretchy IA, Asiedu-Danso M, Kretchy J-P. Medication management and adherence during the COVID-19 pandemic: Perspectives and experiences from low-and middle-income countries. Res Soc Adm Pharm. 2021;17(1):2023-6.

20. Molas E, Luque $S$, Retamero A, Echeverría-Esnal D, Guelar A, Montero $\mathrm{M}_{1}$ et al. Frequency and severity of potential drug interactions in a cohort of HIV-infected patients Identified through a Multidisciplinary team. HIV Clin Trials. 2018;19(1):1-7. 